\title{
Experimental for $\operatorname{Tl}\left[\mathrm{Pt}(\mathrm{CN})_{2}\left(\mathrm{C}_{4} \mathrm{H}_{9} \mathrm{~N}_{4}\right)\right]$ polymer paper:
}

All reagents were used as received without further purification.

$\mathrm{PtCl}_{2}\left(\mathrm{C}_{4} \mathrm{H}_{10} \mathrm{~N}_{4}\right)^{1,2}$ and $\mathrm{AsPh}_{4}\left[\mathrm{Pt}(\mathrm{CN})_{2}\left(\mathrm{C}_{4} \mathrm{H}_{9} \mathrm{~N}_{4}\right)\right]^{2}$ were prepared by established procedures.

$\operatorname{Pt}(\mathrm{CN})_{2}\left(\mathrm{C}_{4} \mathrm{H}_{10} \mathrm{~N}_{4}\right) \cdot \mathrm{H}_{2} \mathrm{O}$ was prepared either by an established procedure ${ }^{2}$ or by the following method: $0.081 \mathrm{~g}$ of $\mathrm{NaCN}(1.6 \mathrm{mmol})$ was added to a yellow solution of $0.206 \mathrm{~g}$ of $\mathrm{PtCl}_{2}\left(\mathrm{C}_{4} \mathrm{H}_{10} \mathrm{~N}_{4}\right)(0.542$ mmol) in $4.0 \mathrm{~mL}$ of 1:1 $\mathrm{NH}_{4} \mathrm{OH}$. The mixture was briefly sonicated and stirred for 10 minutes. $17.0 \mathrm{~mL}$ of $20 \%$ acetic acid in water $(\mathrm{v} / \mathrm{v})$ was added to the stirred solution, affording a mixture of orange and yellow micro-crystals. The stirred reaction mixture was warmed on a hot plate until the orange precipitate turned yellow. Cooling to $0^{\circ} \mathrm{c}$ gave yellow crystals, which were collected on a sintered glass frit and washed successively with water, ethanol and ether. Yield of $\mathrm{Pt}(\mathrm{CN})_{2}\left(\mathrm{C}_{4} \mathrm{H}_{10} \mathrm{~N}_{4}\right) \cdot \mathrm{H}_{2} \mathrm{O}: 99.3 \%$.

$\operatorname{Tl}\left[\mathrm{Pt}(\mathrm{CN})_{2}\left(\mathrm{C}_{4} \mathrm{H}_{9} \mathrm{~N}_{4}\right)\right]$. A solution of $0.0358 \mathrm{~g}$ of $\mathrm{TlNO}_{3}(0.134 \mathrm{mmol})$ in $0.75 \mathrm{~mL}$ of $0.1 \mathrm{M} \mathrm{KOH}$ was added to a solution of $0.0501 \mathrm{~g}$ of $\mathrm{Pt}(\mathrm{CN})_{2}\left(\mathrm{C}_{4} \mathrm{H}_{10} \mathrm{~N}_{4}\right) \cdot \mathrm{H}_{2} \mathrm{O}(0.132 \mathrm{mmol})$ in $1.75 \mathrm{~mL}$ of $0.1 \mathrm{M} \mathrm{KOH}$. Upon standing at room temperature over night, the red polymorph precipitated as long, red, plate-like needles with a green, metallic sheen. This red precipitate was collected on a sintered glass frit and washed with water, ethanol and ether to give the red polymorph in $81.1 \%$ yield. IR (hydrocarbon mull) 666, 1018, 1042, 1055, 1154, 1278, 1407, 1499, 1499, 1526, 1592, 2122 (_CN), 2129 (_CN), 3246, 3431, $3464 \mathrm{~cm}^{-1}$. The yellow polymorph was obtained in approximately $5 \%$ yield by adding $2 \mathrm{~mL}$ of ethanol to the filtrate and allowing the solution to evaporate over night. IR (KBr) 1055, 1269, 1385, 1445, 1537, 1619, 2128 ( CN), 2136 ( C CN), 2856, 2925, 2953, 3420 (broad) $\mathrm{cm}^{-1}$.

Crystal data for $\operatorname{Tl}\left[\mathrm{Pt}(\mathrm{CN})_{2}\left(\mathrm{C}_{4} \mathrm{H}_{9} \mathrm{~N}_{4}\right)\right]$ (red polymorph): Red, plate-like needle with a green, metallic reflection, orthorhombic, space group Pnma, $a=19.504(1) \AA, b=6.1780(4) \AA, c=8.7946(6) \AA, V=$ 1021.7(1) $\AA^{3}, Z=4, D_{\mathrm{c}}=3.671 \mathrm{Mg} / \mathrm{m}^{3}, T=90(2) \mathrm{K} ; \mathrm{R} 1=0.0364, \mathrm{wR} 2=0.0784$ for all data; conventional $\mathrm{R} 1=0.0283$ computed for 1135 observed data $\left(I>2 \_(I)\right)$ with 0 restraints and 83 parameters.

Crystal data for $\mathrm{Tl}\left[\mathrm{Pt}(\mathrm{CN})_{2}\left(\mathrm{C}_{4} \mathrm{H}_{9} \mathrm{~N}_{4}\right)\right]$ (yellow polymorph): Yellow block, monoclinic, space group $P 2{ }_{1} / \mathrm{c}, a$ $=9.137(1) \AA, b=7.122(1) \AA, c=16.715(2) \AA,_{-}=104.815(2)^{\circ}, V=1051.5(2) \AA^{3}, Z=4, D_{\mathrm{c}}=3.567$ 
$\mathrm{Mg} / \mathrm{m}^{3}, T=90(2) \mathrm{K} ; \mathrm{R} 1=0.0438, \mathrm{wR} 2=0.0583$ for all data; conventional $\mathrm{R} 1=0.0280$ computed for 2613 observed data $\left(I>2 \_(I)\right)$ with 0 restraints and 109 parameters.

(1) Tshugajeff (Chugaev), L.; Skanawy-Grigorjewa, M.; Posnjak, A. Z. Anorg. Allgem.

Chem. 1925, 37.

(2) Rouschias, G.; Shaw, B. L. J. Chem. Soc. (A). 1971, 2097.
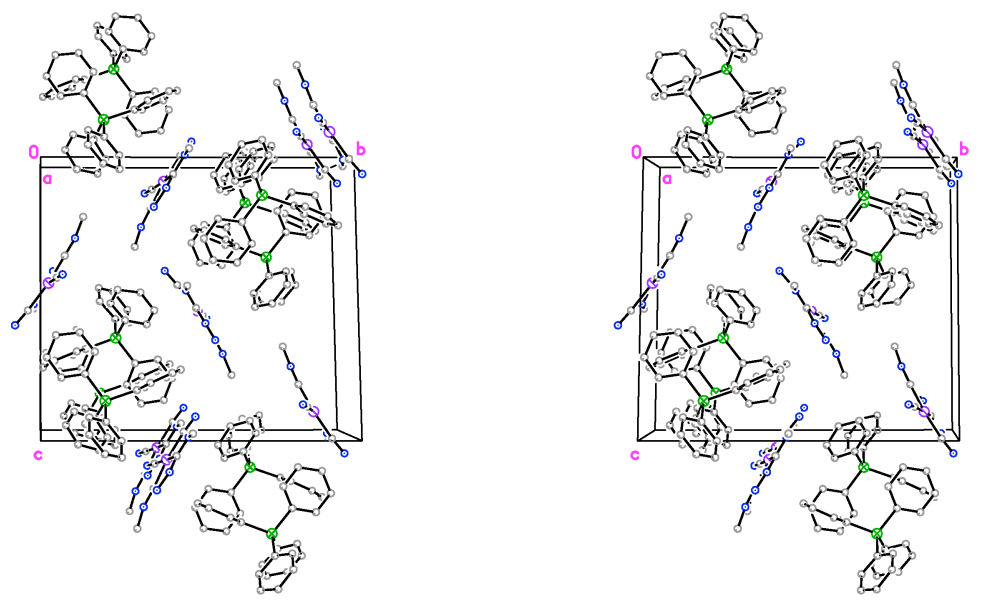

Figure S1. Stereo projection of the unit cell of $\left(\mathrm{Ph}_{4} \mathrm{As}\right)\left[\left(\mathrm{C}_{4} \mathrm{H}_{9} \mathrm{~N}_{4}\right) \mathrm{Pt}^{\mathrm{II}}(\mathrm{CN})_{2}\right] \cdot 3.5 \mathrm{H}_{2} \mathrm{O}$, viewed down the a-axis. Hydrogen atoms and water molecules are omitted for clarity. (Colors of atoms: C, gray; As, green; N, blue; Pt, purple.) 